\title{
RECOVERING THE CORPORATE BRAND: LESSONS FROM AN INDUSTRY CRISIS
}

\begin{abstract}
Purpose: Building on crisis management studies, this paper advances research on brand recovery from the existing focus on product brand/customer dyad into stakeholder marketing and corporate branding.
\end{abstract}

Design/methodology/approach: Uses a single case of industry-dominant corporate brand in an enriched context through in-depth analysis of industry informant and secondary data.

Findings: Uncovers a novel framework of corporate brand and stakeholder interactions designed to recover corporate brand and restore trust in the industry.

Research limitations/implications: The study offers an evidence-based framework of stakeholder interactions designed to support corporate brand recovery (CBR). The rich data are bounded within a single case.

Practical implications: The framework illustrates the importance of drawing on stakeholders in CBR, particularly in an industry crisis, emphasises trust restoration and reveals the peripheral role of customers in corporate brand recovery.

Social implications: The significance of stakeholder networks, particularly in insurance and financial services, in addressing social and ethical issues related to corporate misdeeds is identified.

Originality/value: The study contributes new significant insight to brand recovery research in two ways: firstly, by investigating the recovery of brands at corporate level and, secondly, by revealing the interactions of stakeholders and the corporate brand that are geared towards recovery, all within a stricken industry. 
Key words: corporate brand recovery; trust restoration; stakeholders; financial services; insurance; industry crisis. 


\section{$1 \quad$ Introduction}

Brand crises, for example Ryanair's mis-planning of pilot holidays leading to cancelled flights, VW's deception about emission levels and, more recently O2's upgrade scandal, are salutary reminders that brands can run into trouble at any time, whether through product failure, poor corporate performance, or lapses in social responsibility (Greyser, 2009). In such circumstances, the brand usually, although not always (for example, Ryanair), responds to the crisis through recovery attempts. Existing research into how a brand might be recovered has spanned the effects of brand crises (Dawar and Lei, 2009), possible responses to brand crises (Dutta and Pullig, 2011), negative publicity arising from brand crises (Ahluwalia, Burnkrant and Unnava, 2000; Pullig, Netemeyer and Biswas, 2006) and the management of brand crises (Greyser, 2009). These studies have tended to focus on the dyad of brand/customer with recovery actions largely driven by brand managers targeting the brand's customers. However, current branding theory recognises that managers can no longer unilaterally define and control brand meaning (Vallaster and von Wallpach, 2013), instead, brand value is created by means of social interactions among different stakeholder networks rather than dyadic relationships (Merz, He and Vargo, 2009; Roper and Davies, 2007). With particular relevance to brand crises and recovery, research into crisis management also draws attention to the role of stakeholders in managing crises (Bundy et al. 2017), where their intrinsic value is more likely to generate a favourable outcome (Alpaslan, Green and Mitroff, 2009). Furthermore, the examples of brand crises cited above are instances of corporate brand failure but much of the existing research is concerned with crises at product level (Andrews and Kim, 2007; Cleeren et al. 2013; Klein and Dawar, 2004). Advances in corporate branding (Balmer 1995, 2001; Balmer and Grey, 2003) indicate that a consideration of corporate brand recovery is overdue. Significantly, it is at the corporate brand level where crises trigger a significant loss of trust (Greyser, 2009). 
Allied to work in brand crises, is research into brand contagion or spillover (Dahlén and Lange, 2006; Roehm and Tybout, 2006). Spillover occurs when a crisis in one brand spills over to taint other brands in the same product category (Laufer and Wang, 2018), even though they may be entirely innocent (Cleeren et al. 2008, Cleeren et al. 2013; Dawar and Pillutla, 2000). The significance of spillover for this study is that responses to a brand crisis may not lie solely in the hands of the brand, or even its stakeholders, but within the wider context of the industry, as evidenced by research into tourism (Ritchie, 2004) and insurance (Halan, Sane, and Thomas, 2014). The premise of this study is that brand crises do not occur in a vacuum (for example, Gao et al. 2012; Riddell, 2013) and that for a brand to recover, it needs to engage with its own brand stakeholders and as well as a wider industry network. This research, therefore, offers an in-depth study of a corporate brand within the enriched context of an industry crisis to offer a novel evidence-based framework of corporate brand recovery (CBR), that draws on stakeholder and corporate brand interactions.

This study contributes to the brand recovery literature in several ways. Firstly, it introduces a corporate brand recovery (CBR) framework highlighting the importance of the brand at corporate level in a crisis. Secondly, the study reveals clear linkages between CBR and crisis management, in particular actions taken internally by the corporate brand and external actions by stakeholders, including the need for greater transparency (Jahansoozi, 2006). Thirdly, we provide evidence of the contributions of different stakeholders in recovering the corporate brand and in addressing wider industry initiatives, thereby extending the focus of extant studies from a previous emphasis on the brand/customer dyad (see for example, Cleeren et al. 2013). Efforts to recover a corporate brand need to be made in conjunction with stakeholders, if not a wider network, as other actors can help (or potentially hinder) brand recovery. Fourthly, this study enhances the critical role of trust in CBR and, importantly, the removal of 
distrust. This indicates that trust/distrust is not confined to a brand/customer relationship but a broader range of relationships, for example within a professional network. Finally, this study reveals new recovery efforts extending beyond the established efforts of communication and warranties that firms can adopt to recovery their corporate brand, for example, the optimisation of staff skills and their status.

The paper is structured as follows: theoretical background, the research method, the findings of the research and discussion and a conclusion with the implications and contribution of the research.

\section{Theoretical background}

In this section of the paper, we substantiate the need to adopt a stakeholder approach in brand recovery, going beyond the product brand/customer dyad and that draws on extant literature in crisis management, stakeholders and marketing and corporate branding.

\subsection{Crisis management}

While there is considerable focus in marketing on brand mishaps (Dawar and Lei, 2009; Dutta and Pullig, 2011), research into crises $^{1}$ extends well beyond such failures, providing important insight for CBR. Crisis management should encompass a systematic approach both to detection and prevention (Mitroff, Shrivastava and Udwadia, 1987), usually comprising three distinct stages: pre-crisis prevention, crisis management and post-crisis outcomes (Bundy et al. 2017). Additionally, managers need an external focus on engaging their stakeholders as well as an internal focus on managing the dynamics of the crisis (Pearson and Clair, 1998). By engaging external stakeholders, the firm is more likely to manage the crisis towards a favourable outcome through forming alliances, sharing information and coordinating preparations (Alpaslan et al. 2009). At the same time, by

\footnotetext{
${ }^{1}$ We would like to thank one of the reviewers for this suggestion.
} 
managing the internal dynamics, managers are better positioned to encourage staff to feel positive about the crisis (Johansen, Aggerhold and Frandsen, 2012). Firms will be reliant on stakeholders particularly during the crisis management and post-crisis outcome stages of crisis management (Bundy et al. 2017) and, indeed, what firms say to their various publics at this time influences the extent of the reputational and financial damage inflicted (Coombs, 2007; Coombs and Holladay, 1996).

Whilst the focus of crisis management research rests mainly with the firm, there are contributions from investigations at industry level, where a stakeholder approach is similarly advocated. Ritchie (2004), in developing a strategic approach to crisis management, indicates that sound leadership, robust communications as well as effective stakeholder cooperation, counter fragmented responses in the industry. Similarly, communications with stakeholders were able to improve negative perceptions during crises in the coal industry (Miller and Horsley, 2009). The UK football sector has been prone to several crises over the years where, in spite of cultural readjustments, a failure to enlist stakeholder support is thought to be a factor in continuing upheavals (Elliott and Smith, 2006). Within the insurance industry, which forms the locus of this study, mis-selling insurance products has inflicted heavy costs on both insurers and consumers. It has been suggested that regulation designed to protect consumers has not always been derived from evidence-based studies (Halan et al. 2014). Research, therefore, suggests that crisis management and recovery theory can be strengthened from investigation that acknowledges industry context as well as the role of stakeholders.

\subsection{Stakeholders and brands}

Within marketing, studies have shown that interactions with stakeholders may support firms in gaining competitive advantage (Brodie, Glynn and Little, 2006; Lusch, Vargo, and 
O'Brien, 2007). A firm's relationships with its stakeholders represent a significant resource, all the more so since such relationships are considered valuable, rare and inimitable (Hult et al. 2011; Kull, Mena and Korschun, 2016). The structure of stakeholder relationships has progressed from earlier notions of a hub and spoke model, to views of an interconnected network of relationship consequences (Bhattacharya and Korschun, 2008), where customers, employees, suppliers, as well as competitors, all interact (Maglio and Spohrer, 2013; Ritala, Golnam and Wegmann, 2014). Stakeholder theory in marketing is both normative and aspirational, prompting questions about ethical conduct that prescribe greater engagement with stakeholder networks rather than an exclusive focus customer concerns (Laczniak and Murphy, 2012).

Branding itself has been influenced by stakeholder thinking, leading to the contention that brands evolve not only by intent on the part of the firm but also through a participating stakeholder network (Merz et al. 2009). Significantly, it is not just the brand manager who now defines and controls brand meaning (Gyrd-Jones and Kornum, 2013; Vallaster and Lindgreen, 2011; Vallaster and von Wallpach, 2013) but also customers and other stakeholders (Brodie et al. 2009; Roper and Davies, 2007), who all have distinctive perceptions and interactions with the brand (Lynch and de Chernatony, 2007; Miller and Merrilees, 2013; Miller et al. 2014). The implications of this sense of ownership (Balmer, $1995,2012)$ are that when a brand crisis does occur, stakeholders may feel so betrayed that they engage in negative word-of-mouth and make complaints (McDonald et al. 2010). A brand's history and its reputation may enable managers to anticipate how stakeholders will perceive and react to the crisis (Coombs, 2007), allowing them to stimulate collaboration and co-creation (Scandelius and Cohen, 2016). Research from both crisis management and 
stakeholder thinking suggests that there is considerable scope for a re-appraisal of brand recovery to widen its scope.

\subsection{Recovering the brand}

During or after a crisis, a brand will usually engage in some form of recovery process (Cooper, Miller and Merrilees, 2015), using a range of responses (Dutta and Pullig, 2011). A brand, for example, may deny that there is a crisis, it may remain silent or provide an ambiguous response, or it may offer support for recovery (Dawar and Pillutla, 2000; Laufer and Wang, 2017). The brand may respond using marketing communications, such as advertising (Andrews and Kim, 2007; Muthukrishnan and Chattopadhyay, 2007). Whilst such communications no doubt play a role in combatting a crisis (for example, Coombs, 2007; Coombs and Holladay, 2002), the ability of a brand to weather such an event may already be embedded in existing consumer attitudes (Pullig et al. 2006). Brands that are viewed more positively by consumers are usually better placed to withstand crises (Cleeren et al. 2008; van Heerde et al. 2007). Although it may seem that the first brand caught out in a crisis would be the one most likely to bear the brunt of consumer frustration in a multi-brand crisis setting (Gao et al. 2012), post-crisis brand equity depends on the fit between consumers' prior expectations and firm response (Dawar and Pillutla, 2000). There is, therefore, a lesson to be learnt from the crisis management literature in developing pre-crisis prevention measures (Bundy et al. 2017) in particular, building positive consumer brand attitudes.

For the brand to develop an appropriate response to the crisis, management need to understand the nature of the crisis, for example, whether it is performance or values-related (Dutta and Pullig, 2011; Pullig et al. 2006). A performance-related brand crisis might be product harm, which would endanger the equity of the brand and necessitate product recalls 
(Cleeren et al. 2013; Klein and Dawar, 2004) and/or improved warranties (Andrews and Kim, 2007). The effects of such a crisis may spill over to competitors in the same product category even though these competing brands are guilt-free (Cleeren et al. 2013; Dahlén and Lange, 2006; Roehm and Tybout, 2006). A values-related brand crisis involves social or ethical failures, which undermine the brand's symbolic and emotional benefits and, importantly, trust (Dutta and Pullig, 2011). When a brand crisis does occur, therefore, it is important not to overlook the effect of that crisis on brands competing within the same sector and conversely, how individual brands respond to the brand crises of its competitors (Lei et al. 2008). Such suggestions have led to research in brand spillover (Roehm and Tybout, 2006) and brand contagion (Dahlén and Lange, 2006). Studying brands that have transgressed or 'when brands do bad' reveals marked differences in the type of brand that has 'done bad' and the nature of the transgression (Aaker et al. 2004). For brand recovery research, both the nature of the brand and the type of transgression appear to have an effect on the recovery outcome.

\subsection{Corporate branding and trust}

To date, brand recovery studies contain limited mention of responses at corporate level (Dutta and Pullig, 2011), although it has been noted that the impact of a crisis is influenced by not only the relevance of the crisis but also at what brand level it occurs (Dawar and Lei, 2009). It is, therefore, all the more surprising that existing brand recovery research has neglected corporate branding. Corporate brands differ quite significantly from product brands in terms of disciplinary scope and management (Balmer and Gray, 2003). A firm's corporate branding strategy affects the relationship between its corporate ability and customer attitudes (Berens, van Riel and van Bruggen, 2005), product evaluations (Fetscherin and Usunier, 2012) and the establishment of a corporate brand identity (Aaker et al. 2004). Corporate brands reach multiple, diverse audiences and represent a pledge between the firm and its stakeholder groups (Vallaster et al. 2012). Such a pledge encourages these groups to feel a 
sense of belonging (Hatch and Schulz, 2003) and thus better attuned to problems lying ahead (Balmer, 1995). In times of a crisis, such as the global financial crash, the association that a corporate brand has with other corporate brands may provoke an escalation where the rules of an entire product category may change (Balmer, 2009, 2010).

Significantly, for this research in the insurance sector, it is at a corporate brand level where crises trigger a significant loss of trust (Greyser, 2009). A brand that is trusted is better placed to reduce uncertainty and risk (Chaudhuri and Holbrook, 2001) and is more likely to be forgiven by its customers for any lapses with greater capabilities for recovery (Aaker et al. 2004; Falkheimer and Heide, 2015). In managing a brand, an understanding of trust and how it can be built, maintained and, if necessary, restored can be considered to be a type of inoculation against future infection (Johar et al. 2010). A corporate brand that is trusted may generate favourable thoughts, feelings, beliefs, and opinions (Hoeffler and Keller, 2002, Sichtmann, 2007) and even intimacy (Elliott and Yannapoulou, 2007). These feelings are based on perceptions that the brand is reliable and acts in the interests of the consumer (Delgado-Ballester and Munuera-Alemán, 2001). From a stakeholder perspective, trust forms a vital component of the relationship between the firm and its stakeholders (Hult et al. 2011), so firms should engage frequently in proactive trusting behaviours (Alpaslan et al. 2009). In a crisis, especially one where a brand 'has done bad', it may suffer an erosion of trust or even be actively distrusted. In such circumstances, stakeholders may adjust their attitudes and behaviours to the corporate brand (Adams, Highhouse and Zickar, 2010). In a brand crisis, it would seem that stakeholder trust in a corporate brand can be eroded and even replaced with distrust, making attempts to engage them in recovery singularly challenging. This discussion reveals some shortcomings in brand recovery research that our study aims to address. We aim to advance theory in brand recovery firstly, from a stakeholder perspective 
as suggested both by crisis management research (for example, Alpaslan et al. 2009; Bundy et al. 2017) and marketing (Brodie et al. 2006; Hult et al. 2011) and, secondly from a corporate branding (Balmer, 2009, Greyser, 2009; Vallaster et al. 2012) and industry perspective (Ritchie, 2004). To gain a holistic understanding of the complexities of CBR, the study adopts a single case study design so that stakeholder interactions in corporate brand recovery within an enriched context can be captured.

\section{$3 \quad$ Research method}

The design of the study is based on the assertions in the first part of this paper, that is, corporate brand crises may also involve other brands (Dahlén and Lange, 2006; Roehm and Tybout, 2006), they are context-specific (Miller and Merrilees, 2013, Balmer, 2010) and may draw in other product categories (Cleeren et al. 2013). To uncover the complexities of CBR against this backdrop (Flyvbjerg, 2006), to achieve a naturalistic setting (Piekkari et al. 2009) and to support the elaboration of theory (Eisenhardt and Graebner, 2007), the research was bounded by a single corporate brand dealing with not only its own transgressions (see Aaker et al. 2004) but also with the ongoing misdeeds laid bare in the financial services crises. By focusing on a singular case (Flyvbjerg, 2006), the study was able to achieve both the scope and the depth consistent with the research aims, specifically uncovering the stakeholder interactions in CBR designed to fulfil recovery of the dominant corporate brand. The financial services sector offers a fertile domain for the exploration of how a corporate brand may be recovered particularly all the more so since trust is a critical element in achieving customer satisfaction (Hansen, 2012). Furthermore, the weak differentiation between financial brands may exacerbate the effects of the crisis amongst the competing brands (Dahlén and Lange, 2006), limiting any brand's ability to differentiate itself from its competitors and, to some extent, its fellow miscreants. 
Drawing from a selection of financial corporate brands that were instigating recovery from a crisis $^{2}$ that had affected a number of corporate brands, the authors were able to negotiate access with a single corporate insurance brand, henceforth referred to as the 'focal brand'. This brand operates a multi-channel strategy distributing its products directly to the consumer and via intermediated channels (for example, insurance brokers, retailers), thus generating a dense network of partners and stakeholders. The nature of the corporate brand's own brand crisis concerned breaches of data protection regulations where confidential customer data concerning motor collisions was sold to third parties (claims management companies) and which had been inappropriately sourced when investigating customer claims. Other insurers were also guilty of this behaviour, however in the case of the focal brand, those involved in the breach were sentenced and details of the breach and sentencing featured in a popular daily newspaper, industry trade press and a website reporting on global data breaches. This study forms part of a wider project set within the insurance sector in the UK and direct references to the corporate brand are omitted to ensure its anonymity and to comply with ethical guidelines.

\subsection{Data collection}

Following qualitative and case study research practice, multiple data sources were accessed over a three-year period (2017-2019) to enable the elaboration of theory (Bluhm et al. 2010; Yin, 2018). Primary data were obtained from interviews with informants working for the focal brand. These informants then suggested further informants within the focal brand's stakeholder network, thus following a snowballing process (Patton, 2015). These subsequent interviews were conducted with insurance brokers, competitor insurers, reinsurers, members of the professional insurance body and a local government representative responsible for

\footnotetext{
${ }^{2}$ For example, payment protection insurance mis-selling, unauthorised selling of customer data to third parties and insurance bundling.
} 
financial services. Some of these stakeholders were also part of other brand stakeholder networks, underlining the network intensity. In all, 20 interviews were conducted (see Table 1). The majority of informants were male, reflecting the traditional nature of this industry, falling between 50-60 years of age. Only three informants were female, and these were either comparatively junior within the industry or held positions in the wider financial services sector. A loosely structured interview guide was developed to elicit the interactions between stakeholders supporting the recovery of the focal brand and that of the industry as a whole and included such areas as:

- Focal brand behaviours in recovering the corporate brand

- The nature of the interactions with stakeholders and industry

- Importance of trust in recovering the focal brand and its competitors

- Actions by the industry to recover the focal brand and other brands

The interviews took place either face-to-face in informants' offices or over the telephone. The interviews were recorded with the informants' consent and lasted between 40 and 90 minutes. Notes were taken during and after the interviews so that deeper insight could be obtained from the data (Charmaz, 2006).

In addition to the interview data, two consumer focus groups each comprising seven participants provided further insight into the research. These participants were policyholders holding general insurance (motor, home and pet) policies and when taken together were spread fairly evenly by age and occupation. Group one tended to be older than group two with more participants aged 65 or over and retired. Group two were younger with a higher number of participants aged under 24 and another cluster aged between 45-54; the majority were also in part time work or students. The focus group facilitator introduced topics designed to prompt opinions, views and perceptions of the nature and extent of the crisis has 
had on the focal brand and its insurance products. Each focus group lasted approximately 45 minutes, with the sessions being recorded and transcribed. Notes taken by an observer supplemented the transcripts. 
Table $1 \quad$ Professional informant detail

\begin{tabular}{|c|c|c|c|c|c|}
\hline $\begin{array}{l}\text { Informant } \\
\text { No }\end{array}$ & Organization & Position & Responsibility & Gender & $\begin{array}{l}\text { Age } \\
\text { (years) }\end{array}$ \\
\hline 1 & Focal brand Top 10 & General Manager & UK Operations & Male & $40-50$ \\
\hline 2 & Focal brand & Director & $\begin{array}{l}\text { Marketing Head } \\
\text { office }\end{array}$ & Male & $50-60$ \\
\hline 3 & Focal brand & Employee & $\begin{array}{l}\text { Underwriting Local } \\
\text { branch office }\end{array}$ & Male & $40-50$ \\
\hline 4 & Focal brand & Employee & $\begin{array}{l}\text { Sales force Home } \\
\text { based }\end{array}$ & Male & $50-60$ \\
\hline 5 & $\begin{array}{l}\text { Competitor Top } 15 \\
\text { UK insurance } \\
\text { company }\end{array}$ & Director & Underwriting & Male & $50-60$ \\
\hline 6 & $\begin{array}{l}\text { Competitor Top } 10 \\
\text { UK insurance } \\
\text { company }\end{array}$ & Head of claims. & Claims & Male & $40-50$ \\
\hline 7 & $\begin{array}{l}\text { Competitor Top } 10 \\
\text { UK insurance } \\
\text { company }\end{array}$ & Director & Underwriting & Male & $50-60$ \\
\hline 8 & $\begin{array}{l}\text { Competitor Top } 25 \\
\text { UK insurance } \\
\text { company }\end{array}$ & $\begin{array}{l}\text { Marketing } \\
\text { Manager }\end{array}$ & $\begin{array}{l}\text { Marketing General } \\
\text { Insurance }\end{array}$ & Male & $40-50$ \\
\hline 9 & Reinsurer & Owner/Consultant & Risk Transfer & Male & $50-60$ \\
\hline 10 & Broker & Account manager & $\begin{array}{l}\text { Intermediary } \\
\text { Service }\end{array}$ & Female & $20-30$ \\
\hline 11 & Broker & $\begin{array}{l}\text { Managing } \\
\text { director }\end{array}$ & $\begin{array}{l}\text { Intermediary } \\
\text { Service }\end{array}$ & Male & $50-60$ \\
\hline 12 & Broker & $\begin{array}{l}\text { Commercial } \\
\text { manager }\end{array}$ & $\begin{array}{l}\text { Intermediary } \\
\text { Service }\end{array}$ & Male & $40-50$ \\
\hline 13 & Broker & Owner/Manager & General Insurance & Male & $50-60$ \\
\hline 14 & $\begin{array}{l}\text { Management } \\
\text { Consultant }\end{array}$ & Owner/ consultant & Strategy Advisor & Male & $50-60$ \\
\hline 15 & Professional body & Executive director & UK Insurance & Male & $40-50$ \\
\hline 16 & Professional body & Director & UK Insurance & Male & $30-40$ \\
\hline 17 & Professional body & President & $\begin{array}{l}\text { Local insurance } \\
\text { institute }\end{array}$ & Male & $50-60$ \\
\hline 18 & Professional body & Executive & $\begin{array}{l}\text { Representing } \\
\text { Claims } \\
\text { professionals }\end{array}$ & Male & $50-60$ \\
\hline 19 & Local Government & Industry lead & $\begin{array}{l}\text { Economic } \\
\text { development }\end{array}$ & Female & $30-40$ \\
\hline 20 & $\begin{array}{l}\text { Financial Services } \\
\text { Regulator }\end{array}$ & Consumer Panel & Consumer expert & Female & $60-70$ \\
\hline
\end{tabular}

To accompany the interview and focus group data, electronic and hard copy published documents from a range of sources were consulted as follows: consumer surveys, professional bodies, national, local and industry media as well as material from the website of the focal brand and competitors. Analysis focused on 82 documents which were concerned 
with the focal brand, its recovery and insurance products within the sector (see Table 2). In all, 12 focal brand publications; 39 industry news items including items on other insurance brands; 11 professional body publications; 4 industry body and regulator publications; 7 newspaper items; and 9 industry/consumer surveys generated data relevant to the research purpose.

Table $2 \quad$ Details of secondary data

\begin{tabular}{l|l|l}
\hline Source & Example of sources consulted & $\begin{array}{l}\text { Number } \\
\text { analysed }\end{array}$ \\
\hline Focal brand & $\begin{array}{l}\text { Focal company website: corporate information, press } \\
\text { releases, general information. }\end{array}$ & 12 \\
\hline Insurance industry & $\begin{array}{l}\text { Insurance industry press (e.g. Insurance Times, Post): } \\
\text { websites, press releases, executive speeches (e.g. at } \\
\text { the European Insurance Conference), insurance } \\
\text { events. }\end{array}$ & 39 \\
\hline Professional bodies & $\begin{array}{l}\text { Websites and printed publications, reports and press } \\
\text { releases (e.g. Chartered Insurance Institute conference } \\
\text { news and The Journal). }\end{array}$ & 11 \\
\hline $\begin{array}{l}\text { Industry bodies and } \\
\text { regulators }\end{array}$ & $\begin{array}{l}\text { Association of British Insurers (ABI) website, reports, } \\
\text { speeches and news releases; Financial Conduct } \\
\text { Authority (FCA) website, press releases. }\end{array}$ & 4 \\
\hline National newspapers & $\begin{array}{l}\text { Articles on focal brand and wider insurance context } \\
\text { on website and in press (e.g. Mail on Sunday } \\
\text { newspaper). }\end{array}$ & 7 \\
\hline $\begin{array}{l}\text { Industry/consumer } \\
\text { surveys }\end{array}$ & $\begin{array}{l}\text { ABI reports; The Personal Finance Society (PFS); } \\
\text { YouGov survey. }\end{array}$ & 9 \\
\hline
\end{tabular}

\subsection{Data analysis}

To intensify the rigour of the analysis process, the team created a research database, consisting of all data sets, memos, notes and records of inter-researcher discussions, documents and interview data (Yin, 2018). The authors began the analysis by writing up the memos and transcripts into summaries, which informed interview and document coding (Miles and Huberman, 1994). The team coded the interview content following informants' and participants' own language (in vivo) and then extended this practice across the secondary data sources. The team made constant and repeated comparison of data and found major 
emerging concepts of the phenomenon (Patton, 2015), for example transparency, tangible evidence and mistrust. An unexpected finding was the perceived shortage of talent in the insurance industry which led the analysis to uncover further instances of staff related issues connected to brand crises and ultimately to a whole new category of CBR ('optimising staff skills and status'). As the team read and reread the transcripts, they continuously reiterated between data sets, emerging theory and the literature to develop new interpretations (Pratt, 2008). The team worked together to resolve any quirks in the coding scheme referring to the data, research notes and the literature, following researcher triangulation practice (Denzin, 1978; Farquhar, Michels and Robson, 2020). Alternative explanations such as 'regaining control' were minutely examined as part of the process (Eisenhardt and Graebner, 2007).

When the team had reached agreement, the emergent categories and themes were submitted to a critical practitioner for review (Welch et al. 2002), whose comments contributed to some further reflection. Details of the data map can be found in Figure 1 below and information about stakeholder perspectives are presented in Table 3 in the following section. Suggestions for case study rigour and quality (for example, Eisenhardt and Graebner, 2007; Piekkari et al. 2009) guided the process of establishing credibility, such as triangulation and exploration of alternatives (Beverland and Lindgreen, 2010). These processes supported researcher confidence in the overarching themes as well as the coding and categories. In the following section, the findings of the analysis are presented and enfolded with the literature (Eisenhardt, 1989). Raw data from the multiple data sources are provided for transparency (Beverland and Lindgreen, 2010). 
Figure 1 Data map
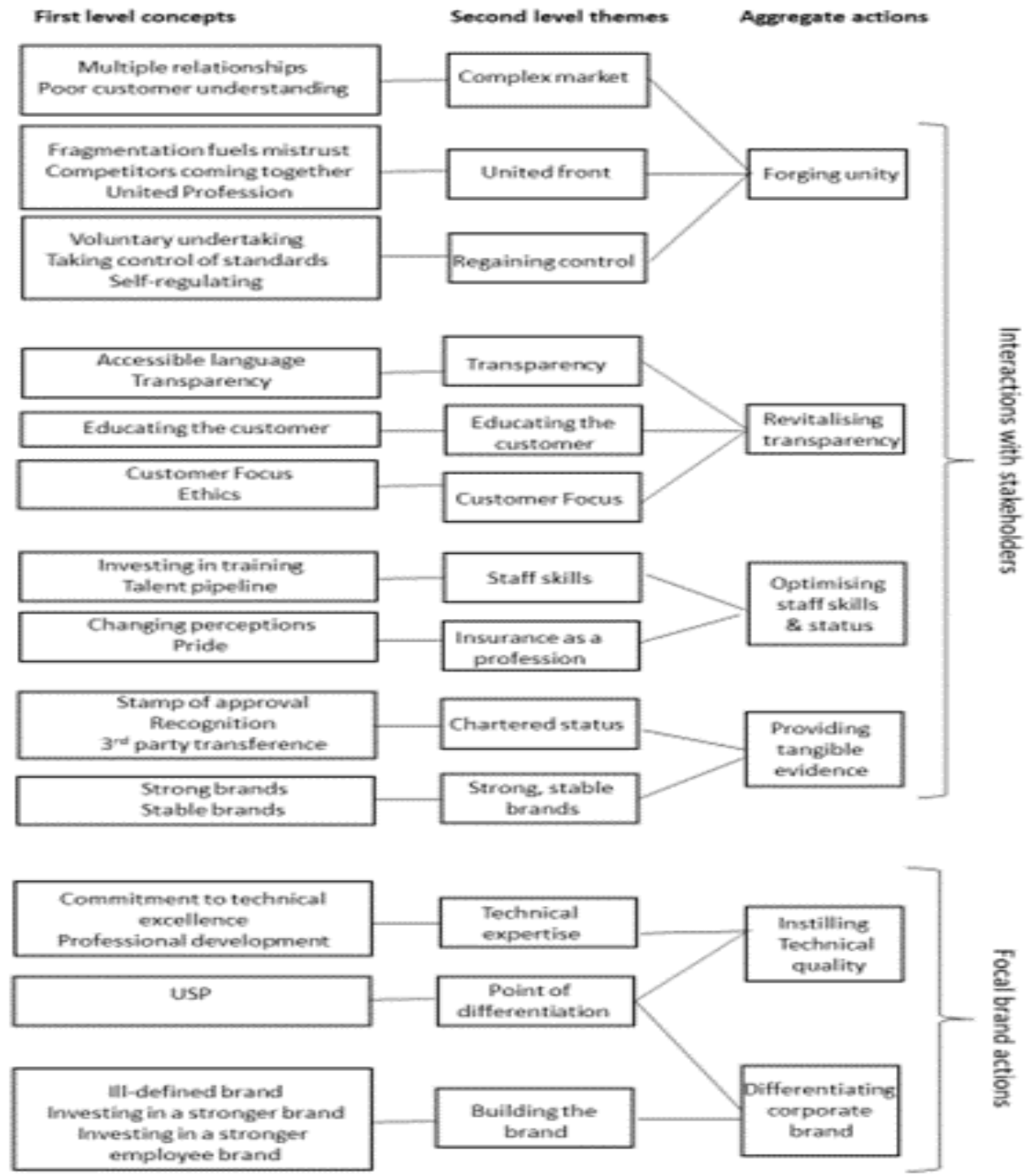

\section{Findings and discussion}

The analysis of the data of the single case uncovered four groupings of stakeholder interactions as part of CBR and as part of a wider industry response as follows: forging unity, revitalising transparency, optimising staff skills and status and providing tangible evidence. The analysis also revealed two distinct sets of actions taken by the focal brand aimed at recovery: instilling technical excellence and differentiating the corporate brand as well as an 
industry-driven objective of restoring trust. The corporate brand recovery framework (Figure 2) and individual stakeholder perspectives on corporate brand recovery (Table 3), developed from the analysis, both advance evidence-based research on CBR.

\subsection{Forging unity}

The forging of unity as part of CBR, and amongst stakeholders and the industry, was a persistent theme across data sources, providing empirical evidence of the complex market and multiple relationships between the corporate brand and its stakeholders (Balmer and Greyser, 2006). The unity, however, seems to be within the industry, and as our study rather surprisingly finds, customers have a weak relationship with the corporate brand. As a result of this weak consumer-corporate brand relationship, the brand crisis further undermines the corporate brand as well as competing brands within the industry. This insurance company informant observes how the poor brand differentiation (Kimpakorn and Tocquer, 2010) of the industry contributes to this industry-wide problem:

Customers don't know the difference between us all. We are all the insurance industry and brokers, loss adjusters, claim handlers and insurers all have an impact.

\section{(informant 7)}

Furthermore, the corporate brand's relationships with various stakeholders appears to have fragmented over time with the crisis refocusing the attention of the industry on the value of these relationships (Kull et al. 2016). It would seem that current efforts to recover the corporate brand should include efforts to build a stronger brand relationship with customers too (Keller, 2012) as recommended by the industry professional body:

.. there is growing recognition that we must travel the same path, sing from the same hymn sheet. It is only by uniting that we can begin to promote insurance as the major economic powerhouse it is. (professional body, trade press) 
Unity amongst professional stakeholders (see Table 3) in CBR was undermined by embedded practices although it was recognised that regaining consumer trust and dismissing any tensions within the network were paramount (Hillebrand et al. 2015). 
Figure 2 A framework for corporate brand recovery

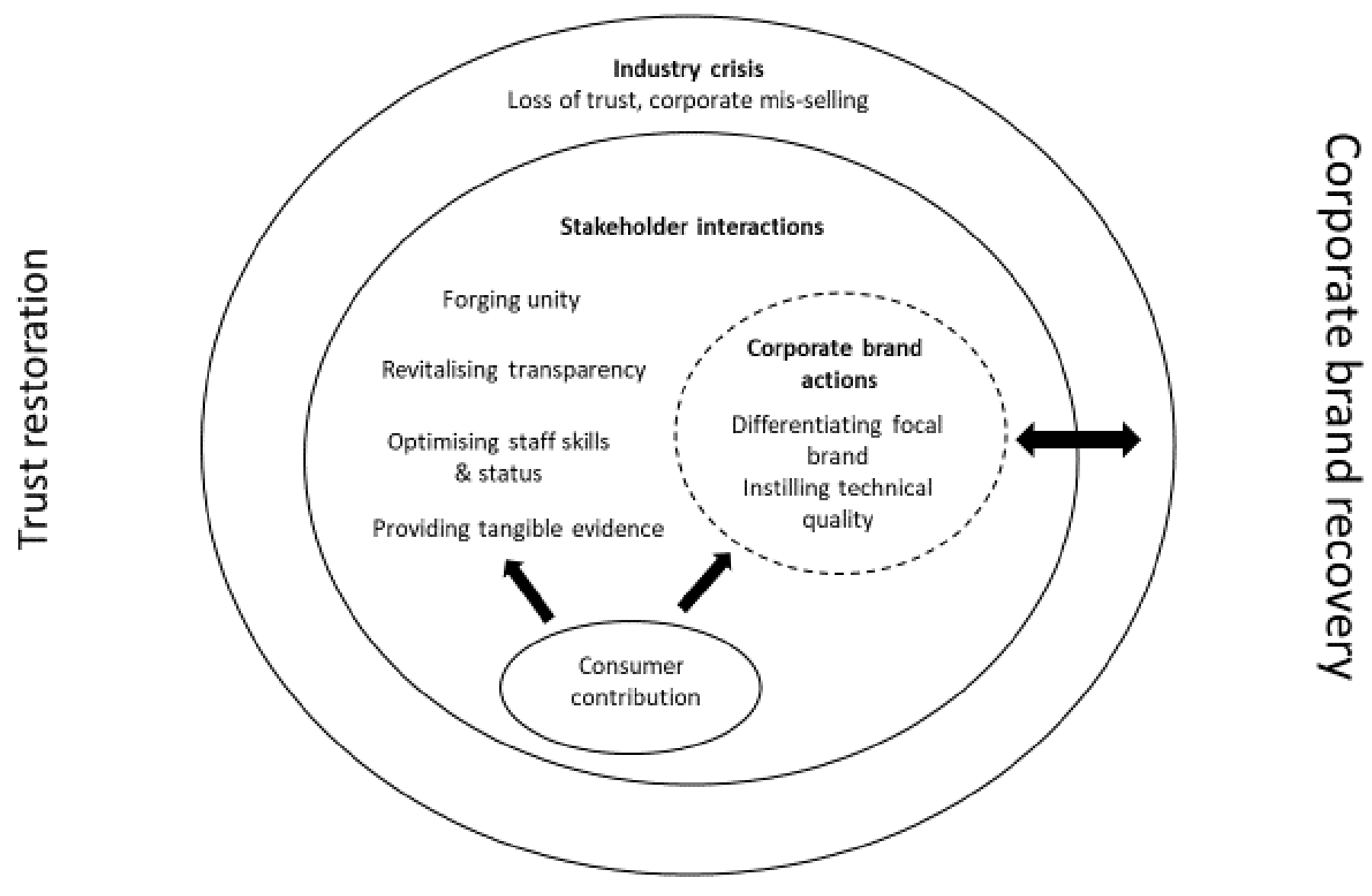


Forging unity also had another important strand, that is, working together to regain control of the market. Calls from the industry stakeholders, specifically insurers and brokers, were to work together to achieve higher levels of compliance and service, to take control and preempt calls for external regulation (for example, Goodhart, 2008). This extract from the insurance trade press refers to the whole industry, directly linking compliance with customer service, as follows:

Let's take our game to a higher level of compliance and higher standards of service.

Not standards that are imposed on us by others. (broker, trade press)

Whilst the findings of this study reveal a degree of unity amongst the professional network, the industry appears to overlook the significance of customers as stakeholders in CBR and quite possibly in the brand. With the growing importance of stakeholders in marketing (for example Brodie et al, 2009; Hult et al. 2011), their significance in CBR, or indeed any other brand endeavours, should not be overlooked.

\subsection{Revitalising transparency}

The second theme emerging from the analysis is concerned with transparency, which has a particular resonance both in corporate marketing research (Leitch, 2017) and crisis management (Jahansoozi, 2006). Analysis of the focus group data revealed customer dissatisfaction with 'small print', that is, the opacity of policy wording; the pricing of the product and the insurance claims process itself. These dissatisfactions are not exclusively those of focal brand but are endemic within the insurance industry and, as such, require a concerted response, as shown in the press statement:

We can only change the public perceptions of the insurance industry by being transparent and educating our customers about the issues we are facing and how these affect premiums. (focal brand, press interview) 
The focal brand may be trying here to reframe customer expectations so that there is a better fit in the future between customer expectations and brand responses (Dawar and Pillutla, 2000). It also has much to gain from recovering its own brand post-crisis.

In addition to the customer focus, transparency was also further underpinned by statements about ethical standards and behaviour, as this industry extract from the insurance professional body illustrates:

Ethical conduct and integrity are central to how a good professional should conduct him or herself. It must be in the DNA of each reputable individual and firm.

(informant 16)

The industry professional body, the Chartered Institute of Insurance (CII), broadly drives ethical conduct and may be able to harness synergies within the industry through strategic stakeholder cooperation (Neville and Menguc, 2006). There is anxiety however that changes in legislation may present further problems for the industry and its brands as this broker observes:

We're worried that the pension reforms will be another mis-selling scandal for those who cannot afford to get advice. (informant 10)

The crisis within the industry and the focal brand has a strong values-related element (Dutta and Pullig, 2011) in that it has crossed ethical boundaries (Trump, 2014). The focal brand and industry can draw on stakeholders to build a stronger normative framework (Laczniak and Murphy, 2012), which may also support trust restoration as discussed below.

\subsection{Optimising staff skills and status}

This theme relating to staff appears more prominently in services branding (for example de Chernatony and Segal-Horn, 2003; O’Loughlin and Szmigin, 2007) than in the brand recovery literature. By engaging staff, the focal brand as well as the industry overall, can 
regain some of the trust that has been lost as recommended in the crisis management literature (Alpaslan et al. 2009). Informants indicated that there was a particular need to increase professionalism across the sector with efforts already underway to train and develop staff, as this professional body informant advises:

We are educating professionals to ensure that they can give the best advice to their customer, be they underwriters, risk managers or claims. (informant 15) Owing to the reputation of the industry, the analysis indicated that there was a shortage of talent, specifically graduates, which was being addressed by changing images of working in call centres. In recognising that staff relationships should be prized (Hult et al. 2011; Kull et al. 2016), the industry, not just the focal brand, acknowledges the importance of attracting talent in recovery. The focal brand with other corporate brands within the sector, is committed to industry initiatives such as the Aldermanbury Declaration, which aims to raise standards, as this professional body informant outlines:

..professionalism, high standards, lifelong learning and ethics [are] at the centre of their business ... as this would result in better outcomes for the customer. (informant 15)

Indeed, the professionalism of insurance staff has become an aspiration of the insurance industry and a key component of the professional body's manifesto (professional body publication/website) which seeks to change perceptions of the industry and position insurance as a profession. Such practices also have implications for crisis management as they enable staff to feel more positive about their role (Johansen et al. 2012). Staff have long been acknowledged as key to branding, with specific research detailing their role as 'brand warriors' (Hatch and Schultz, 2003). This study into CBR complements research in corporate rebranding where staff actions are a major contributor to its success (Muzellec and Lambkin, 2009). Staff who are engaged in rebuilding the reputation of the industry and the 
corporate brand will be better placed to evaluate the impact of mis-selling in the industry crisis.

\subsection{Providing tangible evidence}

The study finds a number of initiatives that contribute to the tangible evidence of the focal brand's recovery, for example, this informant believes that the award of chartered status underpins the status of focal brand:

Chartered is a stamp of approval, it helps signal to employees and brokers what we are about. (informant 2 )

This informant, who works for the focal brand, views such an award as invaluable, as it provides third party transference as a form of independent evidence. Such an award may also reduce the likelihood of transgressions amongst stakeholders and might affect the corporate brand or the industry (Trump, 2014). They go on to explain, that such an award may also confer a measure of brand differentiation:

(our) point of difference .... is we're committed to trying to have higher calibre, professionally qualified experts, better insurance experts than our competition, and, therefore, professional recognition of that is a huge advantage. (informant 2)

The industry might consider aligning their raised professional standards with ethical declarations, consistent with suggestions by Laczniak and Murphy (2012).

Informant responses directly addressed the cause of brand damage, including mis-selling, demonstrating a necessary and substantive change in behaviour (Greyser, 2009). This informant from the focal brand opined that a re-evaluation of the overall significance of branding was emerging:

The insurance industry has tended to assume a strong brand is irrelevant and it is the broker brand you are buying into. However, that completely flies in the face of 
every other intermediated category and everything known from consumer research. (informant 1)

This statement underlines the need for strong branding within the insurance industry, (Farquhar and Robson, 2015). These rather belated attempts at developing a strong corporate brand would also support the instilling of favourable employee attitudes in the insurance industry (Schlager et al. 2011) and recruitment (Wilden, Gudergan and Lings, 2010). These four themes capture stakeholder interactions concerned with CBR and with industry recovery and reveal, in this instance, that there are interactions that are common to both, especially in the 'forging unity' theme. These findings are not inconsistent with earlier studies into brand spillover (Laufer and Wang, 2018; Roehm and Tybout, 2006) demonstrating that brands do not exist in a vacuum. The following two themes denote actions on the part of the corporate brand itself towards recovery. 
Table 3 Stakeholder perspectives on corporate brand recovery showing second-order coding

\begin{tabular}{|c|c|c|c|c|c|c|}
\hline $\begin{array}{l}\text { Stakeholder } \\
\text { description }\end{array}$ & Forging unity & $\begin{array}{l}\text { Revitalising } \\
\text { transparency }\end{array}$ & $\begin{array}{l}\text { Optimising staff } \\
\text { skills and status }\end{array}$ & $\begin{array}{l}\text { Providing tangible } \\
\text { evidence }\end{array}$ & $\begin{array}{l}\text { Instilling technical } \\
\text { quality }\end{array}$ & $\begin{array}{l}\text { Differentiating } \\
\text { the corporate brand }\end{array}$ \\
\hline Focal brand & & & & & $\begin{array}{l}\text { Technical expertise } \\
\text { Point of } \\
\text { differentiation }\end{array}$ & $\begin{array}{l}\text { Building the corporate } \\
\text { brand }\end{array}$ \\
\hline $\begin{array}{l}\text { Competitors } \\
\text { (insurers } \\
\text { including focal } \\
\text { firm) }\end{array}$ & $\begin{array}{l}\text { United front } \\
\text { Complex market } \\
\text { Regaining control }\end{array}$ & $\begin{array}{l}\text { Transparency } \\
\text { Educating the } \\
\text { customer } \\
\text { Customer focus }\end{array}$ & $\begin{array}{l}\text { Staff skills } \\
\text { Insurance as a } \\
\text { profession }\end{array}$ & $\begin{array}{l}\text { Chartered status } \\
\text { Strong stable } \\
\text { brands }\end{array}$ & & \\
\hline Reinsurer & $\begin{array}{l}\text { United front } \\
\text { Complex market } \\
\text { Regaining control }\end{array}$ & Transparency & & & & \\
\hline Brokers & $\begin{array}{l}\text { United front } \\
\text { Complex market } \\
\text { Regaining control }\end{array}$ & Transparency & & Chartered status & & \\
\hline Professional body & $\begin{array}{l}\text { United front } \\
\text { Complex market }\end{array}$ & $\begin{array}{l}\text { Educating the } \\
\text { customer } \\
\text { Transparency }\end{array}$ & Staff skills & Chartered status & & \\
\hline Consumers & Complex market & $\begin{array}{l}\text { Transparency } \\
\text { Customer focus }\end{array}$ & & & & \\
\hline $\begin{array}{l}\text { Financial Services } \\
\text { Regulator }\end{array}$ & & $\begin{array}{l}\text { Transparency } \\
\text { Customer focus }\end{array}$ & & & & \\
\hline $\begin{array}{l}\text { Management } \\
\text { Consultant }\end{array}$ & & Transparency & & & & \\
\hline $\begin{array}{c}\text { Local } \\
\text { Government }\end{array}$ & & & $\begin{array}{l}\text { Staff skills } \\
\text { Insurance as a } \\
\text { profession }\end{array}$ & & & \\
\hline
\end{tabular}




\subsection{Corporate brand actions}

The first set of actions taken by the focal brand itself are major investments in instilling technical quality in its staff as evidenced by their training academy and in-house, industry accredited qualifications with the intention to 'make a virtue out of expertise' (focal firm marketing director, interview). Superior technical, sales and leadership skills also serve as a USP, differentiating or strengthening the identity of a brand through its staff (Kimpakorn and Tocquer, 2010). A competitor informant commented on the prowess of the corporate brand in this area:

Their business is very much focused on technical excellence and that is their USP.

(informant 5)

This strategy will develop existing staff and serve to attract new talent to the company - a challenge identified earlier as characteristic of the insurance industry as noted by this informant:

To staff and prospective staff, it's about the company's commitment to professional development, paying for qualifications. (informant 4)

The provision of advanced training, enhancement of technical knowledge and payment for qualifications clearly signposts the focal firm's investment in training and may indicate awareness that branding is a social interaction process (Vallaster and Lindgreen, 2011). This focus on knowledge is characteristic of a profession and suggests that the focal brand is seeking to position its employees as professionals (Abbott, 1988), thus differentiating the brand from its immediate competitors and possibly from the wider insurance industry. Evidence of technical expertise also contributes to cognitive trust (Cummings and Bromiley, 1996) but, as consumers were not always aware of the brand's technical excellence, plans were put in place to communicate this expertise directly through advertising and working with their stakeholders to achieve chartered status. 
Secondly, the focal brand set about reinforcing and differentiating its brand through marketing communications. Although, already strong with some stakeholder groups, the aim was to minimise any contamination from brands more highly scandalised (Roehm and Tybout, 2006). The message combined the technical aspects of the focal brand with the emotional, in an attempt to develop empathy with consumers through communicating how the insurer understands the stresses and strains of life (marketing industry commentary, website). An appeal to technical and emotional components of the corporate brand (Chaudhuri and Holbrook, 2001) is thought to be important in CBR, specifically restoring trust lost owing to their earlier misdeeds, as this informant asserts:

The advert demonstrates that the company is a company you can trust to look after your insurance needs. (informant 1)

Communications thus remain an important aspect of recovering a brand (Coombs, 2007; Johar et al. 2010); however, in the restoration of trust, the message should be based on evidence as identified by this focal brand informant:

consistent dependability ... everything is as you would kind of expect really from an insurance company, which is "I'm expecting you to be there when I have an issue that I wasn't expecting, and to be dependably secure, to be able to pay out, to be professional', and all of those qualities would characterise the brand image.

\section{(informant 2)}

Informants were fully aware of the need for brand revitalisation both for the needs of the firm but also due to the multiple relationships that exist within this industry, for the industry as a whole as part of attempts at future proofing (Cleeren et al. 2008; van Heerde et al. 2007) or pre-crisis prevention (Bundy et al. 2017. This informant summarises this process as follows: 
We are progressively investing in building a stronger brand which will help us, our brokers and our partners. (informant 2)

Developing a robust brand identity (for example da Silveira, Lages and Simões, 2013; Urde, 2003) or meaningful differentiation (Kimpakorn and Tocquer, 2010) is particularly important for an intermediated insurer, that is one that sells via a number of intermediaries, as the customer may be more familiar with the broker brand than that of the insurer. Stronger equity should offer a direct buffer against crises that may occur in the future (Cleeren et al. 2008), but at the same time, this crisis and its subsequent recovery is a reminder of the significance of contextual factors, such as industry and stakeholders, in brand identity construction (da Silveira et al. 2013). Our findings uncover something of contrast between crisis management and services marketing in recovering crises and failures. In services marketing, a concentration on service failures and recoveries at individual level potentially draws attention away from the "bigger picture" and the multiple stakeholder roles that may trigger a crisis. While in crisis management, customers are acknowledged as key stakeholders but research gives insufficient attention to the customer role in service production (see for example, Elliott, Baron and Harris, 2005).

\subsection{Restoring trust}

The theme of restoring trust emerged very strongly in the analysis as a stakeholder interaction, stated here unequivocally in the insurance trade press:

[we] aim to rebuild trust between a customer and its financial provider through changing the way it does business and truly meeting their needs .. to provide a gold standard customer service. (insurance industry, trade press)

It is recognised that trust plays a pivotal role in corporate branding (Vallaster and Lindgreen, 2011), however this study extends research by finding trust restoration is essential for the recovery of the corporate brand within the industry and for corporate brand stakeholders. 
Interview informants referred to the importance of 'everyone' in the market rebuilding trust and the need to be 'worthy of trust', as this reinsurer informant opines:

I think everyone in the market has a role. I think that's something that as a whole industry we all have to get our act together, and we all have to basically prove that we are worthy of trust. (informant 9)

Again, there is some evidence of a stakeholder perspective here rather than an exclusive customer focus (Laczniak and Murphy, 2012) but this is somewhat undermined by the fragmented structure of the industry, as this insurance competitor notes:

Fragmentation ultimately dis-serves both the public and the industry as a whole, fuelling mistrust and attracting tougher regulation. (informant 7)

Mistrust amongst stakeholders (Arenas, Lozano and Albareda, 2009; Kimbu and Ngoasong, 2013) has been identified as being obstructive in achieving mutual goals. Lack of trust in financial brands is a long-standing problem in financial services (Farquhar and Robson, 2014) and trust restoration will be tempered by perceptions of trust before the crisis (Aaker et al. 2004; Falkheimer and Heide, 2015) as well as embedded distrust; this is clearly identified by the insurance industry and the need for collaboration recognised:

The distrust that existed between different groups in the claims process was impacting negatively on the reputation of the industry as a whole.... Instead of conflict it should be about collaboration. (insurance industry, trade press)

The use of the word distrust here may be significant. As argued above, distrust may not be the same as trust restoration and hence require more strenuous actions by industry and brand stakeholders to minimise negative word-of-mouth and complaints (McDonald et al. 2010). Nonetheless, the corporate brand appeared confident of its ability to demonstrate trustworthy behaviours in reducing risk and uncertainty (Chaudhuri and Holbrook, 2001) and restoring trust with the customer. The findings show that the stakeholder network and the industry 
recognise that trust restoration is a priority. Trust restoration or removal of distrust amongst stakeholders, emerges as a critical dimension of CBR, indicating that trust/distrust is not confined to a brand/customer relationship but extends into the stakeholder network and perhaps beyond.

\section{$5 \quad$ Conclusions}

This study aimed to address shortcomings in existing brand recovery research through an investigation of a single brand, where it uncovered an extended network of stakeholder interactions geared towards the recovery of a corporate brand. Not only were the stakeholder interactions directed at brand recovery but also at the recovery of the industry reputation in the aftermath of the global banking crisis. Stemming from this investigation, there are a number of theoretical implications, which we set out below.

\subsection{Theoretical implications}

The study, firstly, provides emergent theory extending brand recovery research into the area of corporate branding and trust through the introduction of a framework of CBR. As we have argued, crises increasingly occur to brands at corporate level, therefore this study makes an important contribution to studies of brand recovery, which concentrate largely on crises at product or brand level (Dawar and Lei, 2009). Secondly, the study demonstrates clear linkages between CBR and crisis management (Bundy et al. 2017; Mitroff et al. 1987), in particular actions taken internally by the corporate brand and external actions by stakeholders. The findings are also aligned with crisis management research where stakeholder engagement is counselled (Bundy et al. 2017), thus contributing to a stronger ethical stance and a broader perspective on brand actions (Laczniak and Murphy, 2012; Vallaster, Lindgreen and Laon, 2012). Thirdly, and building on the previous contribution, the study amplifies brand recovery research from its previous focus on the brand/customer dyad (for example, Andrews and Kim, 
2007; Cleeren et al. 2013; Muthukrishnan and Chattopadhyay, 2007) by providing evidence of the contributions of stakeholders in recovering the corporate brand and in addressing wider industry initiatives. It is noteworthy in this research how limited a role the customer as a stakeholder plays in CBR. Fourthly, the research supports and enhances the critical role of trust in CBR, at the same time uncovering some equivocation about lack of trust (Falkenheim and Heide, 2015) and distrust. Restoring trust and re-establishing reputation as part of CBR is consistent with studies into corporate brand trust (Sichtman, 2007) but the reduction of distrust is less familiar (see for example Cho, 2006). Trust restoration and even the removal of distrust amongst stakeholders emerges as a critical dimension of CBR, indicating that trust/distrust is not confined to a brand/customer relationship. This contribution is in no small way linked to the critical importance of trust in financial services marketing (Hansen, 2012) but extends that research by revealing a lack of trust amongst insurance professionals and the corporate brand. Finally, this investigation points to recovery efforts extending beyond communication and warranties (for example, Andrews and Kim, 2007), such as the optimisation of staff skills and status as part of stakeholder actions. In spite of the emphasis on forging unity in the framework, there is evidence of schisms amongst the stakeholders, for example the dominance of the broker brand in the intermediated relationship with the customer tends to marginalise the corporate brand, in spite of its resource expenditure. Our study shows that the focal brand directed marketing communications directly at consumers to achieve brand differentiation and to strengthen its brand identity to counter fragmentation in the network.

\subsection{Managerial implications}

For managers, the findings of this research can be summarized under two headings. Firstly, efforts at recovering a corporate brand need to be made in conjunction with their stakeholders, if not a wider industry network. Such brands are closely interconnected with 
other industry actors; so that when an individual corporate brand is damaged, the firm must also be cognizant of other actors and how they can help (or potentially hinder) corporate brand recovery. For an insurance corporate brand, working with other customer-facing stakeholders (such as brokers and claims management companies) to present a strong united front addressing wider industry issues can help to restore its corporate brand. Secondly, the framework provides a template for recovery actions, in particular the restoration of trust. Trust remains a complex issue in practice, with a crisis requiring the restoration of trust particularly with customers and reducing mistrust within the professional networks. Currently, the findings suggest that customers are somewhat peripheral stakeholders, and this may be an indication of challenges that await. Equally, this study highlights the role played by other stakeholder such as staff and notably in this scenario, the professional stakeholder, that is the broker. Given potentially limited resources, firms need to evaluate and prioritise where resources should be invested to restore trust considering their individual context.

In this study, firms were united and responded in a similar way ${ }^{3}$, however if this had not transpired, the focal brand may have been able to positively differentiate itself from competitors and other stakeholders in its recovery efforts. Indeed, it is feasible that stakeholder actions could act as a check that constrained the focal brand's recovery. However, by standing alone, any corporate brand might forgo any benefits flowing from concerted stakeholder actions, for example those identified in this study. The role of a third party, for example, has been highlighted through it orchestrating change, raising ethical standards and providing third party endorsement, which would otherwise be lost. It was the professional body that adopted this third-party role, however, firms could also look to other actors who are perceived as independent to provide this endorsement and foster trust.

\footnotetext{
${ }^{3}$ We would like to thank one of the reviewers for this suggestion
} 


\subsection{Limitations and further research}

The study as with other studies has its limitations. It has investigated CBR within the context of an industry-wide crisis with global ramifications which continue, or at least until very recently, to resonate. The findings accordingly need to be understood within a particular context where it is possible that stakeholders are engaged in recovering the corporate brand as well as the industry. Equally, this study highlights the complex network of interactions that go into recovering brands that 'have done bad' within their stakeholder systems and within the industry. We have made every effort to distinguish between stakeholder interactions directed at $\mathrm{CBR}$ and those concerned with the industry as a whole but acknowledge that there are at times some overlap. With reference to the method, single case study research although generating context-rich data is limited to theory enrichment rather than understanding across different contexts but, as we argue below, these findings establish a firm foundation for further enquiry.

This study opens several avenues for further research. In revealing the interactions of stakeholders in the recovery of a corporate brand, further work might identify the saliency of individual stakeholders (Mitchell et al. 1997). Furthermore, these interactions should also be considered within the context of crisis management, which is currently particularly prominent. The findings also invite reflection on brand identity and how contextual factors influence its construction (da Silveira et al. 2013), for example how might brands with stronger identities cope with industry wide crises? There are indications that strong brands do rather better in such situations (Cleeren et al. 2008; van Heerde et al. 2007). Is this assertion related to a strong identity and if so, in what way? This investigation also uncovers blurred lines between stakeholder interactions directed at recovering the corporate brand and those focused on industry recovery. Are the boundaries between such a brand and its 
industry more permeable than previously understood? This study has investigated the recovery of a corporate service brand and therefore could prompt explicit investigation into how service brands may be recovered. As much of the existing literature is concerned with product brands (for example, Cleeren et al. 2015), it has hopefully opened the way into researching how corporate service brands may be recovered. Finally, the findings of this research have provided evidence of the role of professional bodies in CBR as well as uncovering intricacies within the corporate brand network, for example between the broker, the brand and the consumer and may stimulate investigations into the rebuilding of trust and the eliminate of distrust in consumer brand and professional brand relationships. 


\section{References}

Aaker, J., Fournier, S. and Brasel, S. (2004). "When good brands do bad", Journal of Consumer Research, Vol. 31, No. 1, pp. 1-16.

Adams, J., Highhouse, S. and Zickar, M. (2010), “Understanding General Distrust of Corporations", Corporate Reputation Review, Vol. 13, pp. 38-51 https://doi.org/10.1057/crr.2010.6

Ahluwalia, R., Burnkrant, R. and Unnava, H. (2000), “Consumer Response to Negative Publicity: The Moderating Role of Commitment”, Journal of Marketing Research, Vol. 37, No. 2, pp. 203-214.

Alpaslan, C., Green, S. and Mitroff, I. (2009), "Corporate Governance in the Context of Crises: Towards a Stakeholder Theory of Crisis Management", Journal of Contingencies and Crisis Management, Vol. 17, pp. 38-49.

Andrews, M. and Kim, D. (2007). "Revitalising suffering multinational brands: an empirical study”, International Marketing Review, Vol. 24 No. 3 pp. 350-372.

Arenas, D., Lozano, J. and Albareda, L. (2009), “The Role of NGOs in CSR: Mutual Perceptions Among Stakeholders”, Journal of Business Ethics, Vol. 88, pp. 175-197. https://doi.org/10.1007/s10551-009-0109-x.

Balmer, J. (1995). “Corporate Branding and Connoisseurship”, Journal of General Management, Vol. 21, No 1, pp. 24-46. https://doi.org/10.1177/030630709502100102. Balmer, J. (1998), "Corporate Identity and the Advent of Corporate Marketing", Journal of Marketing Management, Vol. 14, No. 8, pp. 963-996. doi/10.1362/026725798784867536. Balmer, J. (2001), “Corporate identity, corporate branding and corporate marketing: Seeing through the fog", European Journal of Marketing, Vol. 35 No. 3/4, pp. 248-291.

Balmer, J. (2009), “Corporate marketing: apocalypse, advent and epiphany”, Management Decision, Vol. 47, No. 4, pp. 544-572. 
Balmer, J. (2010), “The BP Deepwater Horizon débâcle and corporate brand exuberance”, Journal of Brand Management, Vol. 8, pp. 97-104.

Balmer, J. (2012). "Strategic corporate brand alignment: Perspectives from identity-based views of corporate brands", European Journal of Marketing, Vol. 46. No. 7/8, pp. 10641092.

Balmer, J. (2017), “Advances in corporate brand, corporate heritage, corporate identity and corporate marketing scholarship", European Journal of Marketing, Vol. 51 No: 9/10, pp.1462-1471,

Balmer, J. and Gray, E. (2003), “Corporate brands: what are they? What of them?” European Journal of Marketing, Vol. 37, No 7/8, pp. 972-997.

Balmer, J. and Greyser, S. (2006), “Commentary: Corporate marketing Integrating corporate identity, corporate branding, corporate communications, corporate image and corporate reputation”, European Journal of Marketing, Vol 40, No. 7/8, pp.730-741.

Berens, G., van Riel, C., and van Bruggen, G. (2005), "Corporate Associations and Consumer Product Responses: The Moderating Role of Corporate Brand Dominance”, Journal of Marketing, Vol. 69, pp. 35-48.

Beverland, M. and Lindgreen, A. (2010), "What makes a good case study? A positivist review of qualitative case research published in Industrial Marketing Management, 19712006”, Industrial Marketing Management, Vol 39, pp. 56-63.

Bhattacharya, C. B. and Korschun, D. (2008), "Stakeholder Marketing: Beyond the Four Ps and the Customer”, Journal of Public Policy \& Marketing, Vol. 27, No. 1, pp 113-116.

Bluhm, D., Harman, W., Lee, T. \& Mitchell, T. (2011), “Qualitative Research in Management: A Decade of Progress”, Journal of Management Studies, Vol. 48, No. 8, pp. 1699-1923. 
Brodie, R., Glynn, G. and Little, V. (2006). "The service brand and the service-dominant logic: missing fundamental premise or the need for stronger theory?" Marketing Theory, Vol. 6, No. 3, pp. 363-379.

Brodie, R., Whittome, J. and Brush, G. (2009). "Investigating the service brand: A customer value perspective". Journal of Business Research, Vol. 62, No. 3, pp. 345-355.

Bundy, J., Pfarrer, M., Short, C. and Coombs, W. (2017). "Crises and Crisis Management: Integration, Interpretation, and Research Development", Journal of Management, Vol. 43, No. 6, pp. 1661-1692.

Charmaz, K. (2006), Constructing Grounded Theory, Sage Publications, London.

Chaudhuri, A., and Holbrook. M. (2001), "The Chain of Effects from Brand Trust and Brand Affect to Brand Performance: The Role of Brand Loyalty", Journal of Marketing, Vol. 65, No. 2, pp. 81-93.

Cleeren, K., Dekimpe, M. and Helsen, K (2008), "Weathering product-harm crises”, Journal of the Academy of Marketing Science Vol. 36, pp. 262-270.

Cleeren, K., van Heerde, H. and Dekimpe, M. (2013), "Rising from the Ashes: How Brands and Categories Can Overcome Product-Harm Crises". Journal of Marketing, Vol. 77, No. 2, pp. 58-77.

Cho, J. (2006), “The mechanism of trust and distrust formation and their relational outcomes", Journal of Retailing, Vol. 82, No. 1, pp. 25-35.

Coombs, W. (2007), "Protecting Organization Reputations During a Crisis: The Development and Application of Situational Crisis Communication Theory”, Corporate Reputation Review, Vol. 10, No. 3 pp.163-176.

Coombs, T. and Holladay, S. (1996), “Communication and Attributions in a Crisis: An Experimental Study in Crisis Communication”, Journal of Public Relations Research, Vol. 8, No. 4, pp 279-295, doi 10.1207/s1532754xjprr0804_04 
Coombs, W. and Holladay, S. (2002), "Helping Crisis Managers Protect Reputational Assets: Initial Tests of the Situational Crisis Communication Theory". Management Communication Quarterly, Vol. 16, No. 2, p. 165-186.

Cooper, H., Miller, D. and Merrilees, B. (2015), "Restoring luxury corporate heritage brands: From crisis to ascendency”, Journal of Brand Management, Vol. 22, pp. 448-466. https://doi.org/10.1057/bm.2015.9.

Cummings, L, and Bromiley, P (1996), “The Organizational Trust Inventory (OTI):

Development and validation", Trust in organizations: Frontiers of theory and research Thousand Oaks, CA, Sage Publications. pp. 302-330.

da Silveira, C., Lages, C. and Simões, C. (2013), Reconceptualizing brand identity in a dynamic environment, Journal of Business Research, Vol, 66, No. 1, pp. 28-36.

Dahlén, M. and Lange, F. (2006), “A Disaster Is Contagious: How a Brand in Crisis Affects Other Brands", Journal of Advertising Research, Vol.46 No. 4, pp.388-397

Dawar, N. and Lei, J. (2009). "Brand crises: The roles of brand familiarity and crisis relevance in determining the impact on brand evaluations", Journal of Business Research, Vol 69, No. 4, pp. 509-516.

Dawar, N. and Pillutla, M. (2000), "Impact of Product-Harm Crises on Brand Equity: The Moderating Role of Consumer Expectations”, Journal of Marketing Research, Vol. 37, No. 2, pp. 215-226.

de Chernatony, L. and Cottam, S. (2006), "Internal brand factors driving successful financial services brands", European Journal of Marketing, Vol. 40 No. 5/6, pp. 611-633. https://doi.org/10.1108/03090560610657868

de Chernatony, L. and Segal-Horn, S. (2003), "The criteria for successful services brands", European Journal of Marketing, Vol. 37 No. 7/8, pp.1095-1118. 
Delgado-Ballester, E. and Munuera-Alemán, J-L. (2001), "Brand trust in the context of consumer loyalty”, European Journal of Marketing, Vol. 35, No 11/12 pp. 1238-1258.

Dutta, S and Pullig, C. (2011). "Effectiveness of corporate responses to brand crises: The role of crisis type and response strategies", Journal of Business Research, Vol. 64, No 12 pp. $1281-1287$.

Eisenhardt, K. and Graebner, M. (2007), “Theory Building from Cases: Opportunities and Challenges", Academy of Management Journal, Vol. 50, No. 1, pp. 25-32.

Elliott, D. and Smith, D. (2006), “Cultural Readjustment After Crisis: Regulation and Learning from Crisis Within the UK Soccer Industry". Journal of Management Studies, Vol. 43, pp. 289-317.

Elliott, D., Harris, K. and Baron, S. (2005), “Crisis management and services marketing”, Journal of Services Marketing, Vol. 19 No. 5, 36-345.

https://doi.org/10.1108/08876040510609943

Elliott, R. and Yannopoulou, N. (2007). "The nature of trust in brands: a psychosocial model". European Journal of Marketing, Vol 41, No. 9/10, pp.988-998.

Falkheimer, J. and Heide, M. (2015), "Trust and brand recovery campaigns in crisis: Findus Nordic and the horsemeat scandal". International Journal of Strategic Communication, Vol.9, No. 2, pp.134-147.

Farquhar, J. and Robson, J. (2015). "A Brave New World: Branding in Financial Services". In Harrison, T and Estelami, H (Eds) Routledge Companion to Financial Services Marketing. Routledge, London, pp. 204-218.

Farquhar, J., Michels, N. and Robson, J. (2020), “Triangulation in Qualitative Case Study Research: Widening the Scope”, Industrial Marketing Management, Vol. 87 pp. 160-170. https://doi.org/10.1016/j.indmarman.2020.02.001, 
Fetscherin, M. and Usunier, J-C (2012), “Corporate branding: an interdisciplinary literature review", European Journal of Marketing, Vol. 46, No. 5, pp.733-753.

Flyvbjerg, B. (2006). "Five Misunderstandings About Case Study Research”. Qualitative Inquiry, Vol.12, No. 2, pp.219-245.

Gao, H., Knight, J. Zhang, H. Mather D. and Tan, L. (2012), “Consumer scapegoating during a systemic product-harm crisis”, Journal of Marketing Management, Vol. 28 No 11/12, pp. 1270-1290, DOI: 10.1080/0267257X.2011.645859

Goodhart, C. (2008), “The Regulatory Response to the Financial Crisis”, Journal of Financial Stability, Vol. 4, No. 4, pp. 351-358.

Greenwood, M., Van Buren III, H. (2010), “Trust and Stakeholder Theory: Trustworthiness in the Organisation-Stakeholder Relationship", Journal of Business Ethics, Vol. 95, pp. 425438. https://doi.org/10.1007/s10551-010-0414-4

Greyser, S. (2009). "Corporate brand reputation and brand crisis management”, Management Decision, Vol. 47, No. 4, pp. 590-602.

Gyrd-Jones, R. and Kornum, N. (2013). "Managing the co-created brand: Value and cultural complementarity in online and offline multi-stakeholder ecosystems", Journal of Business Research, Vol. 66, pp.1484-1493.

Halan, M., Sane, R., and Thomas, S. (2014). "The case of the missing billions: Estimating losses to customers due to mis-sold life insurance policies”. Journal of Economic Policy Reform, Vol. 17, No. 4, pp. 285-302.

Hansen, T. (2012). "Understanding Trust in Financial Services: The Influence of Financial Healthiness, Knowledge, and Satisfaction”, Journal of Service Research, Vol. 15, No. 3, pp. 280-295.

Hatch, M-J. and Schultz, M. (2003). "Bringing the corporation into corporate branding, European Journal of Marketing ”, Vol. 37, No. 7/8, pp.1041-1064. 
Hillebrand, B., Driessen P. and Koll, O. (2015). "Stakeholder marketing: theoretical foundations and required capabilities", Journal of the Academy of Marketing Science, Vol. 43, No. 4, pp.411-428.

Hoeffler, S. and Keller, K. (2002). "Building Brand Equity Through Corporate Societal Marketing”. Journal of Public Policy \& Marketing, Vol. 21, No. 1, pp.78-89.

Homburg, C., Jozić, D. and Kuehnl, C. (2017), “Customer experience management: toward implementing an evolving marketing concept", Journal of the Academy of Marketing Science, Vol. 45, pp. 377.

Huber, F., Meyer, F., Vogel, J., Weihrauch, A. and Hamprecht, J. (2013). "Endorser age and stereotypes: consequences on brand age”. Journal of Business Research, Vol. 66, No. 2, pp.207-215.

Hult, G., Mena, J., Ferrell, O.C. and Ferrell, L. (2011), "Stakeholder marketing: a definition and conceptual framework", Academy of Marketing Science Review, Vol. 1, pp. 44-65. Jahansoozi, J. (2006), “Organization-stakeholder relationships: exploring trust and transparency”, Journal of Management Development, Vol. 25 No. 10, pp. 942-955 https://doi.org/10.1108/02621710610708577.

Johansen, W., Aggerholm, H. and Frandsen, F. (2012), Entering new territory: A study of internal crisis management and crisis communication in organizations, Public Relations Review, Vol 38, No. 2, pp 270-279 https://doi.org/10.1016/j.pubrev.2011.11.008. Johar, G., Birk, M. and Einwiller, S. (2010), "How to save your brand in the face of crisis", MIT Sloan Management Review, Vol. 51, No. 4, pp 57-60.

Keller, K. (2012), "Understanding the richness of brand relationships: Research dialogue on brands as intentional agents", Journal of Consumer Psychology, Vol. 22, No. 2, pp. 186-190, https://doi.org/10.1016/j.jcps.2011.11.011. 
Kimbu, A and Ngoasong, M. (2013), “Centralised Decentralisation of Tourism Development: A Network Perspective", Annals of Tourism Research, Vol. 40, pp. 235-259, https://doi.org/10.1016/j.annals.2012.09.005.

Kimpakorn, N. and Tocquer, G. (2010), "Service brand equity and employee brand commitment”, Journal of Services Marketing, Vol. 24 No. 5, pp. 378-388. https://doi.org/10.1108/08876041011060486

Kull, A., Mena, J. and Korschun, D. (2016), “A resource-based view of stakeholder marketing”, Journal of Business Research, Vol. 69, pp 5553-5560.

Laczniak, G. and Murphy, P. (2012), "Stakeholder Theory and Marketing: Moving from a Firm-Centric to a Societal Perspective", Journal of Public Policy \& Marketing, Vol. 31, No. 2, pp. 284-292.

Laufer, D. and Wang, W. (2018), "Guilty by association: The risk of crisis contagion”, Business Horizons, Vol. 61, No. 2, pp. 173-179.

Lei, J., Dawar, N. and Lemmink, J. (2008), “Negative Spillover in Brand Portfolios: Exploring the Antecedents of Asymmetric Effects", Journal of Marketing, Vol. 72, No. 3, pp. 111-123.

Leitch, S. (2017), “The transparency construct in corporate marketing”, European Journal of Marketing, Vol. 51 No. 9/10, pp.

Lynch, J. and de Chernatony, L. (2007), "Winning Hearts and Minds: Business-to-Business Branding and the Role of the Salesperson”, Journal of Marketing Management, Vol. 23, No. 1/2, pp. 123-135.

Lusch, R., Vargo, S. and O’Brien, M. (2007), “Competing through service: Insights from service-dominant logic", Journal of Retailing, Vol. 83, No. 1, pp. 5-18.

McDonald, L., Sparks, B. and Glendon, I. (2010), "Stakeholder reactions to company crisis communication and causes", Public Relations Review, Vol. 36, No. 3, pp. 263-271. 
Maglio, P and Spohrer, J. (2013), “A service science perspective on business model innovation", Industrial Marketing Management, Vol. 42, pp. 65-670.

Merz, M., He, Y. and Vargo, S. (2009), “The evolving brand logic: a service-dominant logic perspective”, Journal of the Academy of Marketing Science, Vol. 37(3) 328-344.

Miles, M. and Huberman, A. (1994), Qualitative Data Analysis (2 ${ }^{\text {nd }}$ Edition). Thousand Oaks, Sage Publications.

Miller, B. and Horsley, S. (2009), "Digging Deeper: Crisis Management in the Coal Industry", Journal of Applied Communication Research, Vol. 37, No. 3, pp. 298-316. DOI: $10.1080 / 00909880903025903$

Mitchell, R., Agle, B. and Wood, D. (1997), “Toward a Theory of Stakeholder Identification and Salience: Defining the Principle of Who and What Really Counts", Academy of Management Review, Vol. 22, No. 4, pp. 853-886.

Mitroff, I., Shrivastava, P. and Udwadia, F. (1987), "Effective Crisis Management", Academy of Management Executive, Vol. 1, pp. 283-292, https://doi.org/10.5465/ame.1987.4275639. Muthukrishnan, A. and Chattopadhyay, A. (2007), "Just Give Me Another Chance: The Strategies for Brand Recovery from a Bad First Impression”, Journal of Marketing Research, Vol. 44, No. 2, pp. 334-345.

Muzellec, L and Lambkin, M. (2009), "Corporate branding and brand architecture: a conceptual framework", Marketing Theory, Vol 9, No. 1, pp. 39-54.

Neville, B. and Menguc, B. (2006), "Stakeholder Multiplicity: Toward an Understanding of the Interactions between Stakeholders", Journal of Business Ethics, Vol. 66, No. 4, pp. 377 391.

O’Loughlin, D. and Szmigin, I. (2007), “Services Branding: Revealing the Rhetoric within Retail Banking”, The Service Industries Journal, Vol. 27, No. 4, pp. 435-452. 
Patton, M. (2015), Qualitative Research \& Evaluation Methods (4th Edition), Thousand Oaks, Sage Publications.

Payne, A., Storbacka, K. and Frow, P. (2008), "Managing the co-creation of value", Journal of the Academy of Marketing Science, Vol. 36, pp. 83-96.

Pearson, C. and Clair, J. (1998), "Reframing Crisis Management”, Academy of Management Review, Vol. 23 No.1, pp. 59-76.

Pearson, C. and Mitroff, I (1993), From crisis prone to crisis prepared: a framework for crisis management. Academy of Management Perspectives, 7, 48-59.

https://doi.org/10.5465/ame.1993.9409142058

Piekkari, R., Welch, C. and Paavilainen, E. (2009), “The Case Study as Disciplinary

Convention: Evidence from International Business Journals", Organizational Research Methods, Vol. 12 No. 3, pp. 567-589.

Pullig, C., Netemeyer, R. G., \& Biswas, A. (2006), “Attitude Basis, Certainty, and Challenge Alignment: A Case of Negative Brand Publicity", Journal of the Academy of Marketing Science, No. 34, pp. 528-542.

Riddell, P. (2013), "Rallying the troops: Crisis communication and reputation management in financial services", Journal of Brand Strategy, Vol. 2, No. 3 pp. 222-227.

Ritala, P., Golnam, A and Wegmann, A (2014), "Coopetition-based business models: The case of Amazon.com”, Industrial Marketing Management, Vol.43, pp.236-244.

Ritchie, B. (2004), “Chaos, crises and disasters: a strategic approach to crisis management in the tourism industry", Tourism Management, Vol. 25, No 6, pp.669-683.

Roehm, M. and Tybout, A. (2006), "When Will a Brand Scandal Spill Over, and How Should Competitors Respond?", Journal of Marketing Research, Vol. 43, No. pp. 366-373.

Roper, S. and Davies, G. (2007), “The Corporate Brand: Dealing with Multiple Stakeholders", Journal of Marketing Management, Vol. 23, No. 1/2, pp. 75-90. 
Scandelius, C. and Cohen, G. (2016), "Sustainability program brands: Platforms for collaboration and co-creation", Industrial Marketing Management, Vol. 57, pp.166-176. Schlager, T., Bodderas, M., Maas, P. and Cachelin, J-L. (2011). "The influence of the employer brand on employee attitudes relevant for service branding: an empirical investigation”, Journal of Services Marketing, Vol. 25, No. 7, pp.497-508.

Shankar, V., Urban, G and Sultan, F. (2002), “Online trust: a stakeholder perspective, concepts, implications, and future directions", The Journal of Strategic Information Systems, Vol. 11, No. 3/4, pp. 325-344.

Sichtmann, C. (2007), "An analysis of antecedents and consequences of trust in a corporate brand”, European Journal of Marketing, Vol. 41, No. 9/10, pp. 999-1015.

Simões, C., Singh, J. and Perin, M. (2015), "Corporate brand expressions in business-tobusiness companies' websites: Evidence from Brazil and India”, Industrial Marketing Management, Vol. 51, pp. 59-68.

Trump, R. (2014), “Connected consumers' responses to negative brand actions: The roles of transgression self-relevance and domain”, Journal of Business Research, Vol. 67 No 9, pp. 1824-1830.

Urde, M. (2003), “Core value-based corporate brand building”, European Journal of Marketing, Vol. 37 No. 7/8, pp. 1017-1040.

Vallaster, C., Lindgreen, A. and Maon, F. (2012), "Strategically Leveraging Corporate Social Responsibility: A Corporate Branding Perspective”, California Management Review, Vol. 54, No. 3, pp. 34-60.

Vallaster, C. and von Wallpach, S. (2013), “An online discursive inquiry into the social dynamics of multi-stakeholder brand meaning co-creation", Journal of Business Research, Vol. 66, No. 9, pp. 1505-1515. 
van Heerde H., Helsen, K. and Dekimpe M. (2007), "The impact of a product-harm crisis on marketing effectiveness", Marketing Science, Vol. 26, pp. 230-245.

Vallaster, C. and Lindgreen, A. (2011), “Corporate brand strategy formation: Brand actors and the situational context for a business-to-business brand", Industrial Marketing Management, Vol. 40, No. 7, pp. 1133-1143. https://doi.org/10.1016/j.indmarman.2011.09.008.

Welch, C., Marschan-Piekkari, R., Penttinen, H. and Tahvanainenen, M. (2002), "Corporate elites as informants in qualitative international business research", International Business Review, Vol. 11, No. 5, pp. 611-628.

Wilden, R., Gudergan, S. and Lings, I. (2010), "Employer branding: strategic implications for staff recruitment”, Journal of Marketing Management, Vol. 26, No.1/2, pp.56-73. Yin, R. (2018), Case Study Research: Design and Methods (Applied Social Research Methods) Thousand Oaks, Sage Publications. 